\title{
QUEEN'S
UNIVERSITY
BELFAST
}

\section{Leniency (Amnesty) Plus: A Building Block or a Trojan Horse?}

Martyniszyn, M. (2015). Leniency (Amnesty) Plus: A Building Block or a Trojan Horse? Journal of Antitrust Enforcement, 3(2), 391-407. https://doi.org/10.1093/jaenfo/jnv005

Published in:

Journal of Antitrust Enforcement

Document Version:

Peer reviewed version

Queen's University Belfast - Research Portal:

Link to publication record in Queen's University Belfast Research Portal

Publisher rights

(c) The Author 2015. Published by Oxford University Press.

This is a pre-copyedited, author-produced PDF of an article accepted for publication in Journal of Antitrust Enforcement following peer review. The version of record Martyniszyn, M 2015, 'Leniency (Amnesty) Plus: A Building Block or a Trojan Horse?' Journal of Antitrust Enforcement, is available online at: http://antitrust.oxfordjournals.org/content/3/2/391

\section{General rights}

Copyright for the publications made accessible via the Queen's University Belfast Research Portal is retained by the author(s) and / or other copyright owners and it is a condition of accessing these publications that users recognise and abide by the legal requirements associated with these rights.

Take down policy

The Research Portal is Queen's institutional repository that provides access to Queen's research output. Every effort has been made to ensure that content in the Research Portal does not infringe any person's rights, or applicable UK laws. If you discover content in the Research Portal that you believe breaches copyright or violates any law, please contact openaccess@qub.ac.uk. 


\title{
Leniency (Amnesty) Plus:
}

\section{a Building Block or a Trojan Horse?}

\begin{abstract}
Marek Martyniszyn*
Leniency (amnesty) plus is one of the tools used in the fight against anticompetitive agreements. It allows a cartelist who did not manage to secure complete immunity under general leniency, to secure an additional reduction of sanctions in exchange for cooperation with the authorities with respect to operation of another prohibited agreement on an unrelated market. The instrument was developed in the United States and, in recent years, it was introduced in a number of jurisdictions. This article contextualises the operation of and rationale behind leniency plus, forewarning about its potential procollusive effects and the possibility of its strategic (mis)use by cartelists. It discusses theoretical, moral, and systemic (deterrence-related) problems surrounding this tool. It also provides a comparison of leniency plus in eleven jurisdictions, identifying common design flaws. This piece argues that leniency plus tends to be a problematic and poorly transplanted US legal innovation. Policy-makers considering its introduction should analyse it in light of institutional limits and local realities. Some of the regimes which already introduced it would be better off abandoning it.
\end{abstract}

Keywords: leniency, leniency plus, amnesty, amnesty plus, immunity plus, bonus plus, selfreporting, deterrence, cartels, whistleblowers, enforcement, penalty plus, omnibus question

JEL Classifications: K21, K42, L13, L40, L49

\section{Introduction}

Leniency plus or amnesty plus ${ }^{1}$ is a tool, which allows a cartelist, who is unable to secure complete immunity under the leniency policy, to cooperate with an antitrust agency ${ }^{2}$ with

\footnotetext{
* Lecturer in Law, Queen's University Belfast. Email: m.martyniszyn@qub.ac.uk. Special thanks to the anonymous reviewers of the JAE, and to D Daniel Sokol, Andreas Stephan, and Bruce Wardhaugh for helpful comments. This paper was presented at the 2014 annual conferences of the Society of Legal Scholars and of the Irish Association of Law Teachers, and at the conference 'the Fight against Hard Core Cartels in Europe' organised by the Centre for Competition Policy (Universidad CEU San Pablo) in November 2014. The author is grateful to participants for their comments. The usual disclaimer applies.

${ }^{1}$ Terms 'immunity', 'leniency', or 'amnesty' are used in different regimes to describe similar instruments of competition law enforcement, allowing a firm participating in a prohibited practice to come forward and receive complete or partial immunity from sanctions in exchange for cooperation with the agency. In the US context it means complete immunity from criminal prosecution for the firm and its cooperating employees, or for the individual only (if she applies on her own). In other regimes, such as the EU, where there are no criminal sanctions, the term 'leniency' is more often used. It describes a possibility of having the fine (for participation in a prohibited agreement) either waived or partly reduced. Hence terms such as 'full immunity' or 'partial immunity', 'leniency'. This article uses the term 'leniency' as a generic one. Compare International Competition Network, Anti-Cartel Enforcement Manual. Chapter 2: Drafting and Implementing an Effective Leniency Policy; Subgroup 2: Enforcement Techniques (May 2009), 2, available <http://www.internationalcompetitionnetwork.org/uploads/library/doc341.pdf>. For discussion of general leniency see eg Nicolo Zingales, 'European and American Leniency Programmes: Two Models Towards Convergence?', 5(1) Competition Law Review 5 (2008); Amedeo Arena, 'Game Theory as a Yardstick for Antitrust Leniency Policy: the US, EU, and Italian Experiences in a Comparative Perspective', 11(1) Global Jurist (2011).

2 Terms 'antitrust' and 'competition law' are used in this article interchangeably. The same applies to terms 'antitrust agencies' and 'competition authority'.
} 
regard to operation of another cartel on an unrelated market. In exchange, the firm benefits not only from immunity in relation to its participation in the second cartel (under the leniency policy), but also from an additional reduction of sanctions for its involvement in the first investigated illegal practice (hence the 'plus'). As an instrument leniency plus is aimed at multimarket cartelists (firms operating on a single market cannot avail of it). As an element of a leniency programme, leniency plus should serve the same goals. It should help to destabilize, uncover and sanction existing prohibited agreements, and deter their creation.

The instrument was developed and is considered to operate successfully in the US. ${ }^{3}$ The recent investigations of numerous auto parts cartels are reported to have been initiated thanks to leniency plus. ${ }^{4}$ As it will be discussed, in the US this instrument is an integral and if applicable - compulsory (not optional) element of the leniency programme. It is often promoted as a tool having 'the potential to bring a series of cartels tumbling down like a house of cards. ${ }^{5}$ In recent years leniency plus - in various forms - was introduced in a number of jurisdictions. ${ }^{6}$ Interestingly, it is not an element of the EU's leniency policy. ${ }^{7}$ In some regimes, for example in Bulgaria, while existing on the books leniency plus has never been used. In at least one jurisdiction it has been removed from the toolbox a few years after its introduction. ${ }^{8}$ International Competition Network's (ICN) Enforcement Manual mentions leniency plus as one of the less-frequently occurring elements of leniency programmes. ${ }^{9}$

This article makes an original contribution by contextualising operation and rationale behind leniency plus, and by forewarning about its potential procollusive effects and the possibility of its strategic (mis)use by cartelists. It points to the limited use of the existing economic models, which focus on the interplay between firms and agencies and disregard the impact of criminal sanctions and leniency for individuals. This article offers also a comparison of leniency plus instruments in eleven jurisdictions. It mitigates optimism about leniency plus. It is claimed that while-from consumers' perspective - it may be a useful tool in some regimes, it is likely to be unnecessary or, worse, anticompetitive in other jurisdictions. This article argues that leniency plus tends to be a poorly transplanted US legal innovation. Policy-makers considering its addition to the enforcement toolbox should consider it in light of institutional limits and local realities.

\footnotetext{
${ }^{3}$ The US Department of Justice (DoJ) Antitrust Division at various occasions reported that over half of its international cartel's investigations were initiated thanks to evidence obtained as a result of investigation of separate industries, or thanks to leads generated during such investigations. Yet it has not been clarified how many commenced thanks to leniency plus itself. See eg Scott D. Hammond, 'Cornerstones of an Effective Leniency Program' (Chilean Competition Day, 9 September 2009), 9, available at <http://www.justice.gov/atr/public/speeches/206611.pdf >.

${ }^{4}$ Compare John M. Connor, 'Is Auto Parts Evolving into a Supercartel?', American Antitrust Institute Working Paper No. 13-06 (2013), at 4, available <http://www.antitrustinstitute.org/sites/default/files/AAI\%20Working\%20Paper\%2013-06.pdf>; Howard W Fogt, 'Global Auto Parts Antitrust Probe: Compliance Programs must be a Top Priority', 22(3) Westlaw Journal Antitrust 1 (2014), at 3.

${ }^{5}$ Thomas O. Barnett, 'Criminal Enforcement of Antitrust Laws: The U.S. Model' (Fordham Competition Law Institute's Annual Conference on International Antitrust Law and Policy, New York, 14 September 2006), 5, available at <http://www.justice.gov/atr/public/speeches/218336.pdf〉.

${ }^{6}$ See Table 1 below.

${ }^{7}$ For listing of some of the regimes which did not introduce this instrument see $\mathrm{n} 55$ below.

${ }^{8}$ Portugal initially introduced leniency plus in 2006. In 2012 this instrument has been removed from the toolbox. Compare Art. 7 of Law 39/2006 of 25 August 2006 available at <http://dre.pt/pdf1sdip/2006/08/16400/61846185.pdf> and Law 19/2012 of 8 May 2012 available at <http://dre.pt/pdf1s/2012/05/08900/0240402427.pdf>.

${ }^{9}$ International Competition Network (n 1) at 5.
} 


\section{Disclaimer re challenges and limits of comparing rules}

When discussing leniency plus comparatively, one must keep in mind at least two differences between competition regimes. First, in some jurisdictions, especially in the US, antitrust violators face criminal sanctions. These are fines (for firms and individuals) and jail sentences. In fact, the US authorities are of the view that holding culpable individuals accountable, by seeking prison time, is the most effective way to deter and punish cartel activity. ${ }^{10}$ Other regimes, in particular the EU, have no criminal sanctions and often no individual sanctions at all. Civil fines imposed on businesses are often the only price to be paid for breaches of competition law. ${ }^{11}$ Second, those regimes which introduced individual sanctions allow individuals to apply for leniency on their own behalf (regardless of whether the firm had done so). ${ }^{12}$ In jurisdictions not foreseeing individual sanctions, there is no individual leniency.

Both differences matter greatly. Threat of individual, especially criminal sanctions (if actively enforced ${ }^{13}$ ) combined with a possibility of securing individual leniency changes the whistleblowing game. The moment individuals are able to avoid sanctions (especially the prospect of jail) leniency becomes more appealing — both for them individually and for firms (as they need to factor in a real possibility of independent individual applications, see Figure 1 below). ${ }^{14}$ In such context, leniency plus may be a promising refinement of the enforcement system. In jurisdictions without individual sanctions and leniency, the situation is different. Cooperation with the authorities is more likely to be part of firm's strategic game (of playing off competitors or worse - the agency after reaping supra-competitive profits), since cartelists run a lesser risk of being uncovered (as there are no individual whistle-blowers acting under threat of sanctions, such as jail time, see Figure 2 below). From this perspective, introduction of leniency plus may be only adding further finesse to firms' strategic games.

These two differences between competition regimes themselves make the comparative discussion of leniency plus challenging. They also remind us that a tool transplanted into different institutional frameworks may have different effects.

\section{Leniency plus in the US-its origin and the place in the toolbox}

${ }^{10}$ Scott D. Hammond, 'The Evolution of Criminal Antitrust Enforcement over the Last Two Decades' (The 24th Annual National institute on White Collar Crime, Miami, 25 February 2010), 11, available at <http://www.justice.gov/atr/public/speeches/255515.pdf>.

11 Some regimes provide for individual civil sanctions. For example, the UK introduced individual disqualification orders for directors involved in cartels. See Andreas Stephan, 'Disqualification Orders for Directors Involved in Cartels', 2(6) Journal of European Competition Law \& Practice 529 (2011).

12 See eg US Department of Justice, Leniency Policy for Individuals (10 August 1994), available at <http://www.justice.gov/atr/public/guidelines/0092.pdf>; Office of Fair Trading, Applications for leniency and no-action in cartel cases. OFT's detailed guidance on the principles and process (July 2013), 2.33-2.37, available at <http://www.oft.gov.uk/shared_oft/reports/comp_policy/OFT1495.pdf>.

13 That is not always the case. For example, in Ireland custodian sanctions for breaches of competition law were introduced in 1996, but since then no single person served a day in jail for such violations (albeit one person served time for failing to pay fine imposed in relation to a breach of competition law). See further Patrick Massey, 'Criminalising Competition Law Offences - A Review of Irish Experience', 3(2) New Journal of European Criminal Law 154 (2012).

${ }^{14}$ It is worth recalling that the first antitrust leniency programme, introduced in the US in 1978, was a failure. Among other deficiencies, it did not extend leniency to employees of the cooperating firms. This changed with the programme's revision in 1993. Moreover, in 1994 the DoJ announced its new leniency policy for individuals, who since then are able to apply for leniency on their own behalf. See US Department of Justice, Corporate Leniency Policy (10 August 1993), available at <http://www.justice.gov/atr/public/guidelines/0091.pdf>; US Department of Justice. 
Leniency plus originates from the US, where it is known under the name 'amnesty plus'. As a policy it began shaping in mid-1990s in the context of the investigations of international cartels. ${ }^{15}$ It was formalised as an element of the leniency programme at the end of the 1990s. ${ }^{16}$

Under the US rules on amnesty plus 'the company can also receive a substantial additional reduction in its fine for its participation in the first offense (i.e., the offense to which the company is pleading guilty)'. ${ }^{17}$ The level of the additional discount (the 'plus' reward) is not fixed. It depends on a number of factors. Relevant considerations are, in particular: ${ }^{18}$ (1) the strength of the provided evidence, (2) the significance of the uncovered violation (in terms of the volume of commerce involved, the geographic scope, and the number of entities involved), and (3) the likelihood of the other conspiracy being uncovered without the voluntary disclosure. ${ }^{19}$ The first two factors carry the greatest weight. ${ }^{20}$ The fact that the scale of the additional reduction is not predefined in the US makes it more difficult for cartelists to use amnesty plus strategically. In the Crompton case - representing the high end of the reductions' spectrum - the firm, which is said to have provided 'exemplary cooperation', benefited from an 'extraordinary' 59\% fine reduction (representing more than $\$ 70$ million) under amnesty plus. ${ }^{21}$ Crompton (later renamed Chemtura) was second-in-the-door (hence, unable to secure immunity from sanctions) in the context of the Antitrust Division's rubber chemicals international investigation. The firm conducted an internal investigation, which lead it to file for leniency on four other markets with combined annual US sales in hundreds of millions. ${ }^{22}$ Moreover, Crompton filed for and secured leniency in Canada and in the EU, what possibly enabled authorities to coordinate their enforcement efforts. The firm was also reported to have disciplined or terminated contracts with individuals involved in or aware of these agreements. It also introduced compliance programme, appointed an ethics and compliance officer, and rewrote its business conducts and ethics code. ${ }^{23}$

What is critical, amnesty plus is not a self-standing and optional instrument in the Antitrust Division's toolbox. It is an integral part of the leniency programme and an element of what can be referred to as a tripartite 'plus package'. This essential circumstance is surprisingly often disregarded in both legal and economic literature. The plus package includes also penalty plus and omnibus question instruments.

\footnotetext{
${ }^{15}$ Donald C. Klawiter, 'Corporate Leniency in the Age of International Cartels: The American Experience', 14 Antitrust 13 (2000), at 14.

${ }^{16}$ For its early formulation see Gary R. Spratling, 'Making Companies an Offer They shouldn't Refuse' (35th Annual Symposium on Associations and Antitrust of the Bar Association of the District of Columbia's, 16 February 1999), 6-7, available at <http://www.justice.gov/atr/public/speeches/2247.pdf>.

17 US Department of Justice, Antitrust Division Manual, 5th ed (March 2014), III-102, available at <http://www.justice.gov/atr/public/divisionmanual/>.

${ }^{18}$ Scott D. Hammond, 'Frequently Asked Questions Regarding the Antitrust Division's Leniency Program and Model Leniency Letters' (19 November 2008), 9, available at <http://www.justice.gov/atr/public/criminal/239583.pdf>.

19 This is assessed by looking whether there was any overlap in the reported conspiracies' corporate participation and among the executives involved.

${ }^{20}$ Hammond (n 18) 9.

21 Scott D. Hammond, 'Measuring the Value of Second-In Cooperation in Corporate Plea Negotiations' (54th Annual American Bar Association Section of Antitrust Law Spring Meeting, 29 March 2006), 2, 14, available at <http://www.justice.gov/atr/public/speeches/215514.pdf>; US v Crompton Corporation, 399 F.Supp.2d 1047 (ND Cal 2005). For trial pleadings see US v Crompton Corporation, 2004 WL 632768 (ND Cal 2005).

22 These were conspiracies among producers of ethylene propylene diene monomers (EPDM) rubber, heat stabilizers, nitrile rubber, and urethanes. Silvestrini Marc, 'Connecticut's Crompton to Plead Guilty to Rubber Chemicals Plot', Regional Business News: Waterbury Republican-American, 16 March 2004.

${ }^{23}$ Andrew Wood, 'Crompton: Trying to Rebuild Confidence', Chemical Week, 24 March 2004.
} 
Penalty plus is frequently referred to as flip side of amnesty plus, ${ }^{24}$ or simply 'the 'stick' side to the amnesty plus carrot'. ${ }^{25}$ If a firm cooperating with the agency does not avails of amnesty plus and does not disclose its participation in another prohibited agreement, and it gets later uncovered and prosecuted, the Division will urge the court to consider that failure - both on behalf of the firm and its executives - as an aggravating sentencing factor. ${ }^{26}$ Hence, from design perspective amnesty plus and penalty plus are not only interlinked, but inseverable. Not availing of the first, should lead to severe consequences under the other. That said, the actual instances of penalty plus application are very rare or not well-reported. A recent case is that of Bridgestone Corporation, which agreed to plead guilty and pay a criminal fine of $\$ 425$ million for price-fixing of certain auto parts. ${ }^{27}$ The fine was significantly increased-under penalty plus - as Bridgestone was earlier involved in the marine hose cartel and although it pleaded guilty ${ }^{28}$ it had not revealed its participation in the auto parts cartel ${ }^{29}$ Noteworthy, Bridgestone decided to litigate in court rather than to settle with the DoJ. The only other reported case involving penalty plus is the one of Hoechst AG. In 2003 this German firm pleaded guilty and agreed to pay $\$ 12$ million fine for participation in a hard-core cartel on the world markets for monochloroacetic acid (MCCAA) ${ }^{30}$ The fine amounted to about $70 \%$ of the volume of affected commerce and it was about $30 \%$ above the maximum fine foreseen in the US Sentencing Guidelines. Moreover, there executives were 'carved out' of the plea agreement. This upward departure from the Sentencing Guidelines was the effect of penalty plus and recidivism. In 1990s the firm was involved in and convicted of price-fixing on another market. It did not disclose then its involvement in the anticompetitive conduct in relation to the MCCAA.

The third element of the plus package only adds to that dynamics. It is a proactive investigatory technique, now routinely used and referred to as the omnibus question. ${ }^{31}$ At the end of an interview the investigators ask witnesses whether they are aware of any other prohibited practices. ${ }^{32}$ Under US rules a cartelist is requited to inform the agency not only about another but about all other prohibited practices, in which it is involved. An individual would be subpoenaed and compelled to provide sworn testimony under the penalty of perjury, ${ }^{33}$ which may include a fine and/ or a prison sentence of up to five years. ${ }^{34} \mathrm{~A}$ witness may not avoid

${ }^{24}$ See eg ibid, at 7.

${ }^{25}$ Hammond (n 3) 11.

26 The Division would pursue a fine or jail sentence at or above (in case of recidivism) the upper end of the US Sentencing Guidance range. US Department of Justice (n 17) at III-103; Scott D. Hammond, 'An Update of the Antitrust Division's Criminal Enforcement Program' (Address before the ABA Section of Antitrust Law Cartel Enforcement Roundtable, Washington, 16 November 2005), 12, available at <http://www.justice.gov/atr/public/speeches/213247.pdf>.

${ }^{27}$ US Department of Justice, 'Bridgestone Corp. Agrees to Plead Guilty to Price Fixing on Automobile Parts Installed in U.S. Cars', 13 February 2014, available at <http://www.justice.gov/atr/public/press_releases/2014/303743.pdf>.

${ }^{28}$ US Department of Justice, 'Bridgestone Corporation Agrees to Plead Guilty to Participating in Conspiracies to Rig Bigs and Bribe Foreign Government Officials', 15 September 2011, available at <http://www.justice.gov/atr/public/press_releases/2011/275025.pdf>.

${ }^{29}$ Fogt (n 4) at 3.

30 Scott D. Hammond, 'Cornerstones of an Effective Leniency Program' (ICN Workshop on Leniency Programs, 22-23 November 2004), 17, n 6, available at <http://www.justice.gov/atr/public/speeches/206611.pdf>. See also US Department of Justice, 'German Chemical Company to Plead Guilty to Criminal Antitrust Conspiracy', 6 February 2003, available at <http://www.justice.gov/atr/public/press_releases/2003/200738.pdf>.

31 Another such technique is 'cartel profiling', which envisages investigating culpable executives' responsibility for firm's activity on other markets as well as identifying their mentors. Hammond (n 3) 10.

${ }^{32}$ US Department of Justice (n 17) at III-102.

${ }^{33}$ Hammond (n 3) 10.

${ }^{34} 18$ US Code $\$ 1621$ (Perjury generally). 
answering, or respond deceitfully without facing the threat of sanctions. Therefore the use of omnibus question reinforces the effectiveness of the amnesty-penalty plus by limiting the circumstances, in which prohibited agreements can remain undetected.

The leniency plus in the US is therefore a part of a broader plus package, which effectively raises the stakes on both ends of the reward-penalty spectrum. There is an extra carrot (leniency plus), but there is also an extra stick (the extra penalty). The omnibus question helps to limit the situations in which one can avoid the carrot-and-stick dilemma. 
Figure 1 Cartelist's (firm's) decision making: US leniency with the tripartite plus package

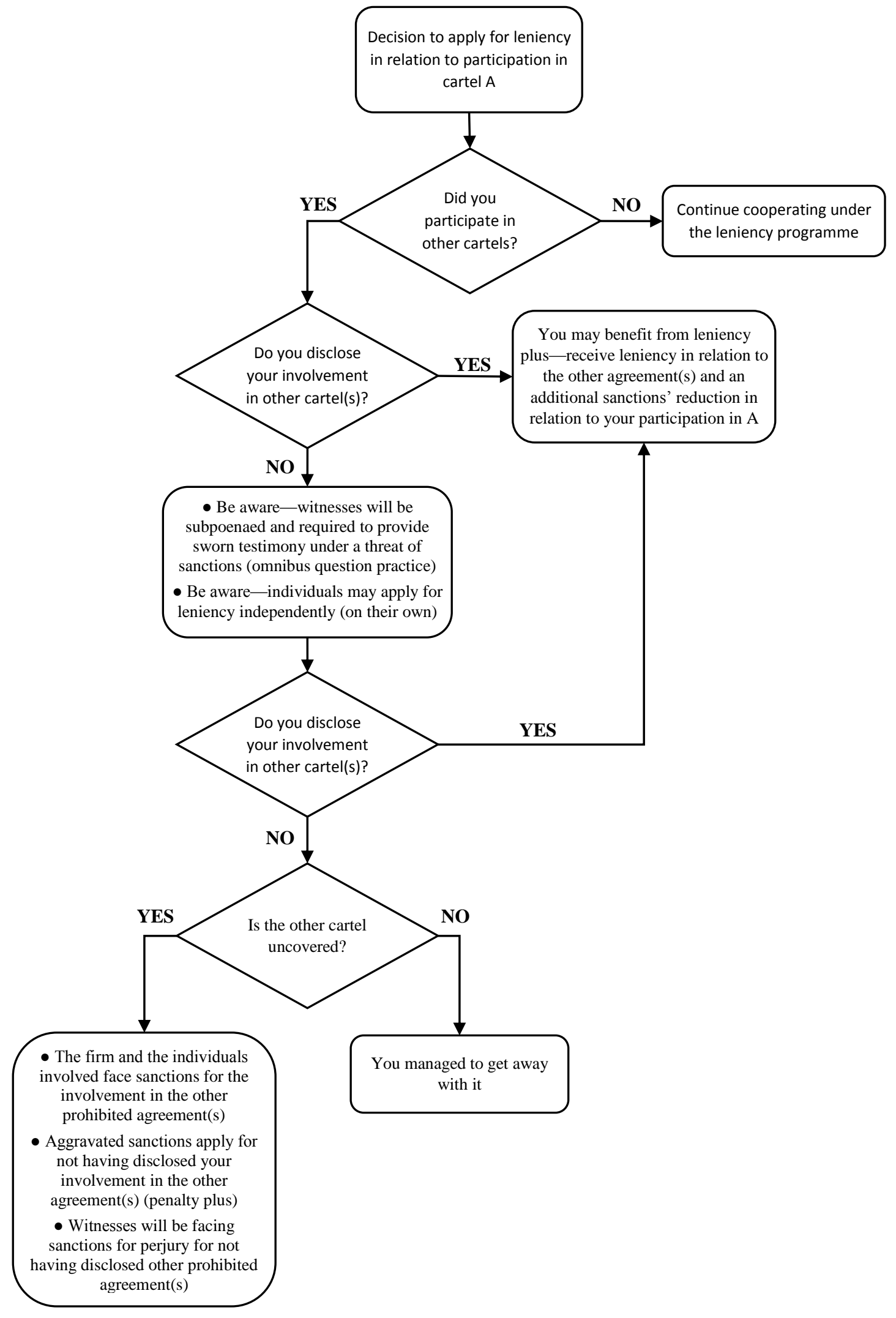


Figure 2 Cartelist's (firm's) decision making: leniency plus without penalty plus \& omnibus question in a jurisdiction without sanctions for individuals.

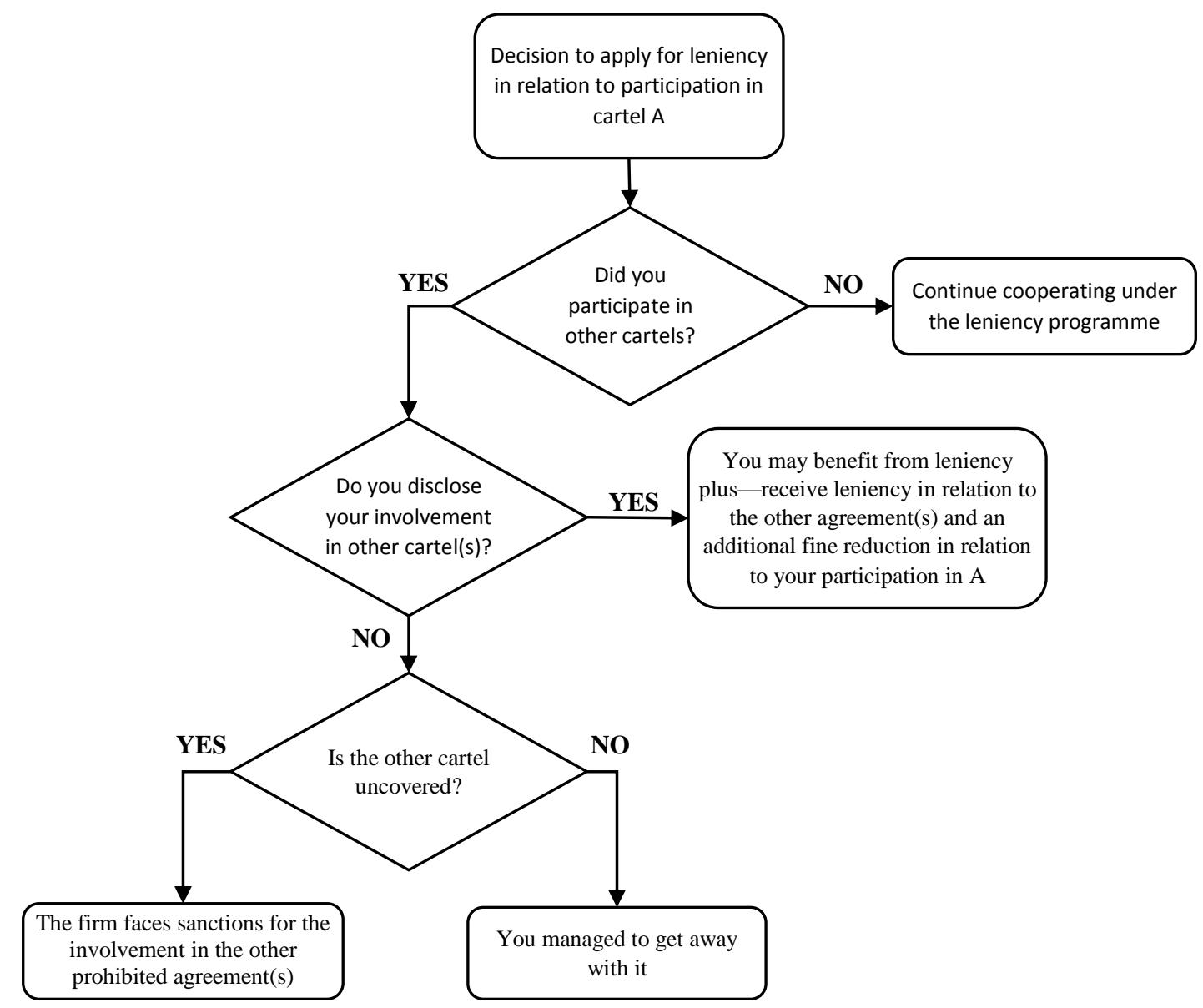

\section{Concerns surrounding leniency plus}

\section{Thin theoretical underpinnings and an imminent threat}

The US international cartels' investigations led to the development of leniency plus. Such cases were and remain particularly challenging, especially due to the fact that the evidence is often located abroad and domestic compulsory legal processes are of limited help. ${ }^{35}$ Through this prism leniency and its further refinement-leniency plus may be seen as carrying a promise of enabling, what would be otherwise frequently impossible — an effective fight against foreign anticompetitive practices. Hence, it was rational for the US authorities to embrace leniency plus and formally add it to the enforcement toolbox. Yet, it is a practice and not theoryinformed instrument. Moreover, leniency plus is generally available and not only in the very specific subset of cases involving foreign entities.

Economists warrant that leniency plus can have adverse, procollusive effects. Its introduction can actually make cartels more, not less, stable. Dijkstra and Schoonbeek

${ }^{35}$ In some cases international cooperation mechanisms, such us mutual legal assistance treaties, can be used to obtain foreign-based evidence. See further Marek Martyniszyn, 'Inter-Agency Evidence Sharing in Competition Law Enforcement', 19(1) International Journal of Evidence and Proof 1 (2015). 
demonstrate that introduction of leniency plus may stabilize cartel formation; that some cartels will be formed, which would not exist under a regime without leniency plus. ${ }^{36}$ Similarly, Lefouili and Roux, using a different model, show that leniency plus can make cartels sustainable in a wider range of circumstances and extend their duration; albeit it also increases firms' incentives to self-report after a first cartel detection. ${ }^{37}$

These models make a valuable contribution to our understanding of the potential consequences of the introduction of leniency plus. Unfortunately, while trying to inform the policy and looking into the US arrangement, they do not attempt to capture the full complexity of the US antitrust enforcement. These models focus on the interplay between firms and agencies, disregarding the important impact of criminal sanctions and leniency for individuals. Even that more limited analysis of the interactions between firms and agencies in the US context, overlooks penalty plus and omnibus question instruments, which change the incentives for firms and individuals. Where these features of the US system factored in, perhaps the overall conclusions on the effects of leniency plus would be different.

Yet, even these restricted models are useful. In many jurisdictions some features of the US system (eg criminal sanctions, individual leniency, penalty plus) are not present. This makes the theoretical findings of possible procollusive effects of leniency plus more directly relevant and suggests that policy-makers should be - at the very least-cautious when considering introduction of leniency plus and designing it. This is further warranted by the results of a recent, extensive practitioners' survey in the US showing that strategic use of leniency (for example, to punish competitors) is a significant phenomenon. ${ }^{38}$

\section{Moral dilemma behind the 'plus'}

From moral perspective leniency plus may be viewed as problematic. It is an additional reward for an entity which has participated in more than one prohibited agreement. In case of leniency, the waiver or the reduction of the sanction is a reward for full cooperation with the agency (including the provision of evidence). Given the difficulties involved in uncovering and dealing with cartels and the fact that leniency's introduction has a long-term effect of changing the market game (as its existence is another factor to be considered by any current and prospective violators), this reward may be viewed as justified.

In case of leniency plus, a violator benefits from leniency with regard to the other disclosed agreement. That is not problematic - that reward is justified on the just stated grounds. But what basis are there for granting the violator the additional - the 'plus' - reduction in relation to its participation in the firstly reported prohibited agreement? The violator does not provide any additional information (beyond that already provided under leniency). Should it be able to capitalize twice on the same 'service' rendered to the agency? It seems that the answer lies in the long-term impact of leniency plus. If it furthers distrust among current and prospective cartelists, if it additionally destabilizes cartels and helps prevent their creation, then perhaps the 'plus' is a fair price to pay for that long-term effect. Yet, since the economists suggest that it does not have to be so, that leniency plus may actually have procollusive effects, then this

\footnotetext{
${ }^{36}$ Peter T Dijkstra and Lambert Schoonbeek, 'Amnesty Plus and Multimarket Collusion' (2009), available at <http://www.webmeets.com/files/papers/EARIE/2009/201/paper.pdf>.

${ }^{37}$ Yassine Lefouili and Catherine Roux, 'Leniency Programs for Multimarket Firms: The effect of Amnesty Plus on Cartel Formation', 30(6) International Journal of Industrial Organization 624 (2012).

${ }^{38}$ D. Daniel Sokol, 'Cartels, Corporate Compliance and What Practitioners Really Think About Enforcement', 78 Antitrust Law Journal 201 (2012), at 212.
} 
instrument poses a difficulty. Moreover, as discussed in the next section, leniency plus may also weaken deterrence.

The situation is perhaps somewhat mitigated when the additional reward under leniency plus is linked - as in the US system - with the additional penalty under penalty plus, and the practice of omnibus question. In such context, a cartelist has no choice-either it cooperates fully and discloses all prohibited agreements, or she faces greater sanctions for not having done so. The 'plus' reward can be seen then as a quid pro quo for coming completely clean. There is a value in it as fewer resources will be consumed to investigate firm's other possible, yet uncovered violations; and the signal will be sent to other market participants (including current and prospective cartelists) that that particular firm is no longer member of any prohibited agreement. Penalty plus is there in the background to act as a sanction for abusing this process of cooperating and coming clean. Such a more nuanced framework mitigates, if not fully solves, the moral dilemma behind leniency plus.

\section{Systemic problems}

Deterrence is one of the aims of competition law enforcement. To be effective, it should be based on a credible threat of sanctions of sufficient scale to exceed the benefits from engaging in a prohibited conduct. ${ }^{39}$ The probability of detection and punishment must also be factored in. In regimes imposing only corporate fines for antitrust violations, ${ }^{40}$ such as the EU, a minimum fine to deter anticompetitive conduct should 'equal the expected gains from the violation multiplied by the inverse of the probability of a fine being effectively imposed' ${ }^{41}$ In the context of collective violations, such as cartels, the same logic applies both to individual violators and the cartelists taken together. ${ }^{42}$

Various commentators argue that fines currently imposed for antitrust violations are too low to secure optimal deterrence. ${ }^{43}$ In jurisdictions relying only on fines, sub-optimal ones cause under-deterrence. Fines reductions under leniency programmes may weaken deterrence further, if they go beyond compensating increase in the probability of detection and successful

\footnotetext{
${ }^{39}$ For classic formulations of the optimal deterrence theory see Gary S Becker, 'Crime and Punishment: An Economic Approach' in Gary S Becker and William M Landes (eds), Essays in the Economics of Crime and Punishment (UMI, 1974); William M Landes, 'Optimal Sanctions for Antitrust Violations', 50(2) The University of Chicago Law Review 652 (1983); George J. Stigler, 'The Optimum Enforcement of Laws', 78(3) Journal of Political Economy 526 (1970). See further Bruce Wardhaugh, Cartels, Markets and Crime: A Normative Justification for the Criminalisation of Economic Collusion (CUP, 2014) 92-101.

${ }^{40}$ This articles does not attempt to analyse the inter-relationship between different types of sanctions in competition law enforcement (such as prison sentences and disqualification orders) and their joint deterring impact. Such examination warrants a separate, independent study.

${ }^{41}$ Wouter P. J. Wils, 'Optimal Antitrust Fines: Theory and Practice', 29(2) World Competition 183 (2006), at 191. Note that Wils differentates this 'deterrence' approach from 'internalization' approach advocated by Becker and Landes. The latter approach provides that it is not optimal to eleminate all violations since some of them are efficient in economic terms. It is underpinned by the Chicago School belief that antitrust should have total economic welfare (not consumer welfare) at its heart. See further Becker (n 39), Landes (n 39).

${ }^{42}$ Compare ibid, at 202.

${ }^{43}$ See eg Emmanuel Combe and Constance Monnier, 'Fines Against Hard Core Cartels in Europe: the Myth of Overenforcement', 56 Antitrust Bulletin 235 (2011); John M Connor, 'Optimal Deterrence and Private International Cartels' (2007), available at <http://ssrn.com/abstract=787927>; Yuliya Bolotova, et al., 'Factors Influencing the Magnitude of Cartel Overcharges: an Empirical Analysis of the U.S. Market', 5(2) Journal of Competition Law and Economics 361 (2008); Cento Veljanovski, 'Cartel Fines in Europe-Law, Practice and Deterrence', 30(1) World Competition 65 (2007).
} 
prosecution. ${ }^{44}$ For example, Veljanovski showed that in the EU fines actually paid by violators were reduced by forty-five percent on average by leniency and he argues that the EU leniency programme 'appears over-generous'. ${ }^{45}$ In such a context, the introduction of leniency plus has the potential to further weaken deterrence, possibly undermining the whole enforcement system, as it leads to the reduction of total sanctions imposed on a cartelist for its participation in prohibited agreements. It may lead to the worst possible outcome: society bearing the cost of competition law enforcement without a valid return in the form of reduced rate of collusion. ${ }^{46}$

\section{Leniency plus - in whose interest?}

As with all policies, also in the context of antitrust various groups, market participants lobby in their favour. In case of leniency plus some of the important stakeholders are multimarket firms, law firms, antitrust agencies, and consumers.

Since leniency plus is aimed at firms operating at more than one market, they are the principal stakeholder. It is rational to assume that most lobbying on their side - if any — will be in favour of poor leniency plus design, allowing firms to exploit it and use strategically for their own benefit. ${ }^{47}$ Cartels are profitable so cartelists have funds necessary to attract skills and knowhow necessary to structure cartel involvement strategically, ${ }^{48}$ in order to maximise supracompetitive profits, while minimising the firm's exposure to fines. Introduction of leniency plus may make this game only more elaborate. ${ }^{49}$

Law firms, generally, are likely to lobby in favour of leniency plus in any serviceable form (that is, in a form which actually leads to some leniency plus applications), since a new instrument will likely create workload and hence billable hours. From law firms' workload perspective it does not matter whether the leniency plus regime is pro- or anticompetitive.

The true danger lies with the antitrust agencies. They may be tempted-but should notfavour leniency plus as a tool even if it is not good for consumers. Agencies care about their public relations and tend to act to justify their existence (and their budgets). They like to show the public at large that they are successful in performing their functions. ${ }^{50}$ Leniency plus can potentially help agencies to open more investigations and improve their statistics. It carries a low-hanging fruit of more cases, which are also easier to win. It is so, even if the instrument

${ }^{44}$ For more on leniency programmes' design and their possible effects see eg Massimo Motta and Michele Polo, 'Leniency Programs and Cartel Prosecution', 21(3) International Journal of Industrial Organization 347 (2003).

${ }^{45}$ Veljanovski (n 43) at 75.

${ }^{46}$ In this vein Buccirossi and Spagnolo when commenting on three scenarios: (1) costly enforcement with effective deterrence, (2) no enforcement, (3) costly enforcement with little or no deterrence. Paolo Buccirossi and Giancarlo Spagnolo, 'Optimal Fines in the Era of Whistleblowers. Should Price Fixers still Go to Prison?' in Vivek Ghosal and Johan Stennek (eds), The Political Economy of Antitrust (Elsevier, 2007) 96.

${ }^{47}$ Firms which do not or did not partake in anticompetitive activities are more likely to focus on their core business and other regulatory lobbying (eg in the areas of corporate liability, IP protection, etc.), instead of investing scarce resources in trying to influence the design of new antitrust enforcement tools.

${ }^{48} \mathrm{Cf}$ n 38 above and text accompanying.

${ }^{49}$ In similar vein Wils notes that 'successful cartels tend to be sophisticated organisations, capable of learning. It is thus safe to assume that cartel participants will try to adapt their organisation to leniency policy, not only so as to minimise the destabilising effect, but also, where possible, to exploit leniency policies to facilitate the creation and maintenance of cartels.' Wouter P. J. Wils, Efficiency and Justice in European Antitrust Enforcement (Oxford: Hart, 2008) para 422.

50 That is well illustrated by the antitrust agencies often recalling the cumulative amounts of imposed fines or jail sentences, which numbers are clearly intended to be perceived—and often sadly are — as a proxy of agency's effectiveness. 
itself is poorly thought through, prone to strategic use by conspirators and actually contributing to consumer harm. Moreover, younger or less-established agencies may favour introducing leniency plus also because it may be presented - to the public, domestic and foreign counterparts - as a smart move. It may be advanced as a case of learning from the best practice of more experienced colleagues, arguably enhancing the reputation of the implementing agency.

Consumers should be in favour only of such leniency plus instruments which serve consumer welfare in the long term. Yet consumers, at large, do not represent their interests well. ${ }^{51}$ The area of antitrust is particularly technical and one should not expect that consumers' positions will be well-represented in any dialogue on new policy proposals. ${ }^{52}$

\section{Leniency plus around the world}

Although competition law enforcers and commentators often talk about cross-fertilisation between regimes, it seems that when one looks into the US system it seems that the fertilisation works one way - outwards, with US policies and practices are being exported, transplanted elsewhere. Leniency plus is one such example. After being developed in the US, in recent years it was introduced in various forms in other regimes.

The importance of rules design need not be explained to a legal audience. As will be discussed, in some regimes leniency plus was designed and implemented in ways which additionally (beyond the raised theoretical, moral and systemic concerns) question its effects and make it particularly prone to strategic use by cartelists. Therefore, it may often be a case of an unsuccessful or failed legal transplantation. ${ }^{53}$

As discussed, in the US leniency plus is designed in such a way that a cartelist when applying for leniency is obliged to report not only one, but all prohibited agreements it is, or should be, aware of. By not doing so, it exposes itself to aggravated sanctions under penalty plus. Hence, leniency plus is a compulsory (not optional) part of the leniency programme. Due to the omnibus question practice, witnesses are asked about any prohibited agreements under the threat of sanctions for perjury. Since the cartelist is required to reveal all prohibited agreements, it is entitled to benefit from the additional, 'plus' reward only once. ${ }^{54}$ The scale of the reward is not known ex ante. It is determined by the agency in the light of the relevant factors. Hence, the strategic use of the instrument is more difficult. Against this backdrop this article turns now to provide an overview of leniency plus rules in eleven jurisdictions which

\footnotetext{
${ }^{51}$ Consumer groups tend to lack resources (as compared with business pressure groups), and they often have different viewpoints, making it difficult to secure adequate representation and exercise effective pressure on the policy-makers. See generally Colin Scott and Julia Black, Cranston's Consumers and the Law, 3rd ed. (Butterworths, 2000) 12-18.

52 That said, at the international level some effort is being put to incorporate consumers' perspective into working of the International Competition Network - currently the leading platform of competition law and policy dialogue. See eg Phil Evans, 'On the ICN in Rio: maps and the meaning of thongs' available at $<$ http://judoeconomics.wordpress.com/2012/05/03/on-the-icn-in-rio-maps-and-the-meaning-of-thongs/>.

${ }^{53}$ For more on legal transplants see Nuno Garoupa and Anthony Ogus, 'A strategic interpretation of legal transplants', 35(2) Journal of Legal Studies 339 (2006); Jonathan M Miller, 'A Typology of Legal Transplants: Using Sociology, Legal History and Argentine Examples to Explain the Transplant Process', 51(4) The American Journal of Comparative Law 839 (2003); Pierre Legrand, 'The Impossibility of Legal Transplants', 4 Maastricht Journal of European \& Comparative Law 111 (1997).

${ }^{54}$ See above $\mathrm{n} 21$.
} 
introduced it. ${ }^{55}$ Brief insights into a few regimes which implemented leniency plus differently is followed by a more general comparison and commentary.

\section{Canada}

In Canada leniency plus is known under the name 'immunity plus'. Similarly to the US model, in Canada a cartelist is required to reveal to the Competition Bureau 'any and all' prohibited agreements it is aware of. ${ }^{56}$ In case of failure to do so the Bureau may recommend increased penalties for the offences which should have been discovered by the applicant and disclosed. If the applicant knew about such offences but failed to report them, the Bureau will call for increased penalties and it may also move to revoke the immunity altogether. ${ }^{57}$ The latter element makes the Canadian penalty plus policy stand out as the most stringent one internationally. Canada also embraced the US omnibus question practice. Witnesses are asked about any criminal activity they are aware of under a threat of criminal charge of obstruction under the Competition Act, ${ }^{58}$ and perjury or obstruction under the Criminal Code. ${ }^{59}$ The scale of the additional reduction under immunity plus is not predefined and is likely to be in the range of five to ten percent. ${ }^{60}$

\section{$\boldsymbol{U K}$}

In the UK's regime an applicant for leniency does not have to disclose all prohibited agreements it is involved in. There are no penalty plus or omnibus question instruments. ${ }^{61}$ In effect, leniency plus is only an optional element of the leniency programme. Moreover, a cartelists is presumably allowed to avail of it a few times in order to reduce sanctions for its involvement in the same prohibited agreement. ${ }^{62}$ The UK's leniency plus is not particularly generous. The level of the additional reduction is not stipulated. The agency sets it in light of the circumstances, yet it is 'not likely to be high'. ${ }^{63}$ That said, in at least one case the UK's agency granted an additional reduction of 25 percent under leniency plus. ${ }^{64}$

\footnotetext{
${ }^{55}$ Leniency plus is not available in the EU regime, nor it is available in the following jurisdictions: Argentina, Australia, Belgium, China, Cyprus, Denmark, Estonia, Finland, France, Germany, Greece, Hong Kong, Hungary, India, Indonesia, Ireland, Japan, Latvia, Lithuania, Luxembourg, Mexico, Netherlands, Norway, Portugal (see above n 8), Romania, Russia, Slovakia, Slovenia, South Africa, Spain, Sweden, Taiwan, Turkey, and Ukraine. In some regimes which have not formally adopted leniency plus, additional cooperation may be taken into account (as a mitigating factor) by the agency when setting the fine.

${ }^{56}$ Competition Bureau, Bulletin- Immunity Programs under the Competition Act (7 June 2010), Para 17(b), available at <http://www.competitionbureau.gc.ca/eic/site/cb-bc.nsf/vwapj/Immunity-Program2010.pdf/\$FILE/Immunity-Program-2010.pdf>.

${ }^{57}$ Competition Bureau, Immunity Program: Frequently Asked Questions (5 August 2014), Q42(4), available at <http://www.competitionbureau.gc.ca/eic/site/cb-bc.nsf/eng/03594.html>.

${ }^{58}$ Under Section 64 of the Canadian Competition Act.

${ }^{59}$ Competition Bureau (n 57) at Q42(7).

${ }^{60} \mathrm{Ibid}$, at Q43(4).

${ }^{61}$ Office of Fair Trading (n 12) at 5.23-5.24.

${ }^{62}$ Compare ibid, at 9.4.

${ }^{63}$ Ibid, at 9.3 .

${ }^{64}$ Office of Fair Trading, Decision No. CA98/06/2003, Price-fixing of Replica Football Kit, Case CP/0871/01 (2003), paras 16 and 661. In another case a firm was granted a reduction of ten percent under leniency plus. See Office of Fair Trading, Decision No. CA98/01/2010, Tobacco, Case CE/2596-03 (2010), paras 2.93 and 8.118. In some cases the OFT did not explicitly stipulate the scale of the leniency plus uplift. See eg Office of Fair Trading, Decision No. CA98/01/2005, Collusive tendering for mastic asphalt flat-roofing contracts in Scotland, Case CE/1925-02 (2005), para 410; Office of Fair Trading, Decision No. CA98/01/2006, Collusive tendering for flat roof and car park surfacing contracts in England and Scotland, Joined Cases CE/3123-03 and CE/3645-03 (2006), para 859.
} 


\section{Switzerland}

In Switzerland leniency plus is known under the name 'bonus plus'. It is an optional element of the leniency programme. An applicant for leniency, who did not qualify for immunity, may receive up to a 50 percent fine reduction. If she avails of leniency plus and discloses also another unknown cartel that reduction-enlarged thanks to leniency plus-may reach 80 percent, effectively setting a maximal leniency plus uplift at a level of 30 percent. ${ }^{65}$ The leniency plus provisions were first time applied in 2010 with an applicant securing an overall (in total) discount of 60 percent. $^{66}$

\section{South Korea}

In South Korea leniency plus is an option within the leniency programme. The size of the leniency plus reduction is determined by the size relation between the initially and later disclosed prohibited agreements. The baseline leniency plus reduction is 20 percent. If the other disclosed agreement (or agreements - the South Korean rules explicitly envisage a scenario in which a leniency plus applicant discloses more than one agreement) is bigger (in terms of turnover) than the initially reported agreement, yet not twice as big, the reduction is 30 percent. If the other agreement is more than twice bigger, but less than four times, the reduction is 50 percent. If it is four times bigger, the leniency plus warranties fine exemption (full reduction of the fine for participation in the initially reported agreement) ${ }^{67}$ Given the generosity of South Korean leniency plus rules, they are particularly prone to strategic misuse by cartelists.

\section{Poland}

The 2014 Amendment Act ${ }^{68}$ introduced leniency plus to Polish regime. ${ }^{69}$ Leniency plus is an optional part of the leniency programme. The additional reduction is predefined and set rigidly at the very high level of 30 percent. The rules do not preclude also benefiting from the additional reduction multiple times with regard to the same fine.

Table 1 Summary of Rules on Leniency Plus

\begin{tabular}{|c|c|c|c|c|c|c|}
\hline Regime & $\begin{array}{c}\text { leniency } \\
\text { plus-a } \\
\text { compulsory } \\
\text { or optional } \\
\text { element of } \\
\text { the leniency } \\
\text { programme? }\end{array}$ & 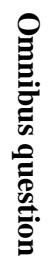 & 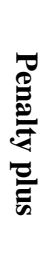 & $\begin{array}{l}\text { Is an applicant } \\
\text { required to } \\
\text { disclose } \\
\text { participation in } \\
\text { all prohibited } \\
\text { agreements? }\end{array}$ & $\begin{array}{c}\text { Is the 'plus' reward } \\
\text { pre-defined? }\end{array}$ & $\begin{array}{l}\text { Can a firm reap the 'plus' } \\
\text { reward a number of times } \\
\text { (in relation to the same } \\
\text { underlying fine)? }\end{array}$ \\
\hline
\end{tabular}

${ }^{65}$ Art. 12, Verordnung über die Sanktionen bei unzulässigen Wettbewerbsbeschränkungen

(KG-Sanktionsverordnung, SVKG) of 12 March 2004, available at <http://www.admin.ch/opc/de/classifiedcompilation/20040326/index.html>.

${ }^{66}$ Competition Commission (ComCo), WEKO sanktioniert Preisabreden im Bau-Nebengewerbe (4 November 2010), available at <http://www.news.admin.ch/NSBSubscriber/message/attachments/21071.pdf〉.

${ }^{67}$ Korea Fair Trade Commission, 'Notification on Implementation of Cartel Leniency Program' (2009), Art. 16 , available <http://eng.ftc.go.kr/files/static/Legal_Authority/Notification\%20on\%20Implementation\%20of\%20Cartel\%20L eniency\%20Program(2009).pdf>.

68 The Act of 10 June 2014 amending the Act on the Protection of Competition and Consumers and the Code of Civil Procedure, published in the Official Journal of 17 July 2014, item no 945, available at <http://isap.sejm.gov.pl/Download?id=WDU20140000945\&type=2>. For discussion of these recent changes see Marek Martyniszyn and Maciej Bernatt, 'On Convergence with Hiccups: Recent amendments to Poland's Competition Law’, 36(1) European Competition Law Review 8 (2015).

${ }^{69}$ See Art. 113 d of the Act of 16 February 2007 on the Protection of Competition and Consumers, as amended. 


\begin{tabular}{|c|c|c|c|c|c|c|}
\hline US & compulsory & $\sqrt{ }$ & $\sqrt{ }$ & yes & $\begin{array}{l}\text { no, but it can be } \\
\text { significant }\end{array}$ & $\begin{array}{l}\text { no, but the scale of the } \\
\text { reward depends on a number } \\
\text { of factors }\end{array}$ \\
\hline Canada & compulsory & $\sqrt{ }$ & $\sqrt{ }$ & yes & $\begin{array}{l}\text { no, typically in the } \\
\text { range of } 5-10 \%\end{array}$ & $\begin{array}{l}\text { no, but the scale of the } \\
\text { reward depends on a number } \\
\text { of factors }\end{array}$ \\
\hline UK & optional & $x$ & $x$ & no & $\begin{array}{l}\text { no, 'not likely to be } \\
\text { high' but at least one } \\
\text { case of } 25 \% \text { reduction } \\
\text { identified }\end{array}$ & possibly \\
\hline $\begin{array}{c}\text { New } \\
\text { Zealand } 1\end{array}$ & optional & $x$ & $x$ & no & no & possibly \\
\hline Singapore $^{2}$ & optional & $x$ & $x$ & no & no & possibly \\
\hline Switzerland & optional & $x$ & $x$ & no & $\begin{array}{l}\text { yes, reduction up to } \\
30 \%\end{array}$ & possibly \\
\hline South Korea & optional & $x$ & $x$ & no & $\begin{array}{l}\text { yes, reductions of } 20, \\
30,50 \text { and } 100 \%\end{array}$ & $\begin{array}{l}\text { see the rules on calculating } \\
\text { the leniency plus reduction }\end{array}$ \\
\hline Brazil $^{3}$ & optional & $x$ & $x$ & no & $\begin{array}{l}\text { yes, set at the level of } \\
33 \% \text { (one-third) }\end{array}$ & possibly \\
\hline Bulgaria $^{4}$ & optional & $x$ & $x$ & no & $\begin{array}{l}\text { yes, reduction up to } \\
10 \%\end{array}$ & $\begin{array}{l}\text { yes, explicitly foreseen; total } \\
\text { reductions under leniency } \\
\text { plus cannot exceed } 30 \%\end{array}$ \\
\hline Poland $^{5}$ & optional & $x$ & $x$ & no & $\begin{array}{l}\text { yes, set at the level of } \\
30 \%\end{array}$ & possibly \\
\hline Italy $^{6}$ & optional & $x$ & $x$ & no & $\begin{array}{l}\text { yes, reduction up to } \\
50 \%\end{array}$ & possibly \\
\hline
\end{tabular}

<http://www.comcom.govt.nz/the-commission/commission-policies/cartel-leniency-policy/cartel-leniency-policy-andprocess-guidelines/>.

${ }^{2}$ Competition Commission Singapore, Leniency Programme, available at <http://www.ccs.gov.sg/content/ccs/en/Educationand-Compliance/ccs_leniency_programme.html>.

3 Conselho Administrativo de Defensa Economica (CADE), Programa de Leniencia available at <http://www.cade.gov.br/Default.aspx?80a063ad729090aabe9fb4>. Compare Ministry of Justice, 'Fighting Cartels: Brazil's Leniency Program', 3rd ed (2009), para 2.9, available at <http://www.cade.gov.br/upload/Brazil_Leniencia_Program_Brochure.pdf >.

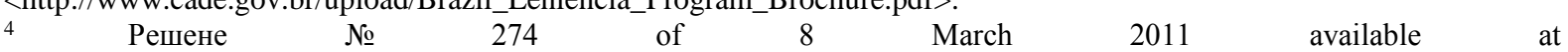
<http://www.cpc.bg/storage/file/Decision\%20Leniency\%20New\%202011.doc>.

5 The 2014 Amendment Act introducing leniency plus came into force on 18 January 2015. Compare notes 68-69 above and accompanying text.

${ }^{6}$ Leniency plus was added to Italian regime only recently through Guidelines on antitrust fines, which were adopted in October 2014. See Linee Guida sulla modalità di applicazione dei criteri di quantificazione delle sanzioni amministrative pecuniarie irrogate dall'Autorità in applicazione dell'articolo 15, comma 1, della legge n. 287/90, para 24, available at <http://www.agcm.it/trasp-statistiche/doc_download/4498-lineeguidacriteriquantificazionesanzioni.html>.

\section{General comparison}

Table 1 provides an overview of the key features of the leniency plus instruments around the world. Only in the US - the jurisdiction which developed this instrument - and Canada leniency plus, if applicable, is a compulsory part of the leniency programme. In all other regimes it is an option-cartelists cooperating with an agency may, but are not required to avail of it. This is a first factor making it a tool susceptible to misuse. Moreover, in some jurisdictions in which leniency plus is an option the levels of the leniency plus reduction (the leniency plus uplift) were predefined. This in itself need not to be detrimental, but in some cases the uplifts are set in a rigid manner (stipulating a particular percentage rather than a reductions' range). For example, in Brazil and Poland the uplifts are set not only at very high levels (33 and 30\%), but they are also unconditional in the sense that an applicant fulfilling the formal conditions will benefit from the reduction regardless of, for example, the significance of the other revealed prohibited agreement. Furthermore, in some of the regimes a cartelists may, explicitly or potentially, avail of a leniency plus uplift more than once, in order to reduce the same fine. 
This is particularly worrying, especially if one compares that construction with the US or Canadian solutions, requiring companies to come completely clean. ${ }^{70}$

These last two design flaws may be exploited by multimarket cartelists. They may be engaging in more cartels, some of them also of little significance, in order to use them in future as tools lowering their exposure to fines for participation in more substantial prohibited agreements. These threats of potential misuse of leniency plus come on top of the earlier identified theoretical, moral, and systemic concerns relating to leniency plus, raising a serious question about the tool's design and the appropriateness of its introduction.

\section{Conclusions}

Leniency plus is an element of leniency programmes allowing a cartelist who did not secure a complete immunity to get an additional sanctions' reduction (the plus) in exchange for disclosing the agency some other prohibited agreement on an unrelated market. It is a practicebased tool, developed in the US in the context of international cartels investigations and considered by the US agency a successful instrument. Yet, economists show that leniency plus can have procollusive effects. Moreover, the instrument poses a moral dilemma as an additional reward is granted to multimarket firms which participated in more than one prohibited agreement.

In recent years leniency plus was transplanted into other jurisdictions. As argued in this piece these were in most cases only partial implementations. It seems that little attention was devoted to the instrument's place in the broader US plus package and the overall US antitrust enforcement system. While in the US leniency plus - when applicable - is compulsory (requiring firms to come completely clean under the threat of aggravated sanctions) in many other regimes it is an optional tool. Most jurisdictions introduced only the extra carrot (the additional reduction of sanctions) but no extra sticks (no penalties for not availing of it despite being involved in more cartels), leaving leniency plus prone to strategic misuse. Moreover, some regimes predefined the level of additional reductions and made it possible to use leniency plus multiple times in relation to the same underlying sanction. Such design flaws create incentives for multimarket firms to partake in more than one illegal agreements so as to game the system and avail of extra carrots (additional sanctions' reductions) if needs be. Hence, leniency plus becomes a tool potentially serving cartelists, not the consumers.

If properly designed leniency plus may be a useful tool in regimes with individual leniency and sanctions (especially of a criminal nature). Agencies which have the capacity and resources to robustly enforce competition laws, for example by challenging multimarket, often international cartelists, may put it to good use. In other regulatory frameworks and in regimes which enforcement priorities are different or resources are particularly scarce, policy-makers should abstain from introducing leniency plus as it can have procollusive effects, it may weaken deterrence, and could be exploited by cartelists. Authorities in such regimes will be better off by piggy-backing on the enforcement efforts of more resourceful, foreign counterparts. It is only rational for a multimarket cartelist which has applied for leniency, for example, in the US to file for leniency in other affected jurisdictions which actively enforce competition laws. It needs no further incentives such as further reductions of sanctions. These jurisdictions which added leniency plus to the enforcement toolboxes, but lack individual leniency and sanctions, should abandon it.

\footnotetext{
${ }^{70}$ See also n 21 above.
} 
